\title{
Derry and the Magician
}

\section{Mrs. John Hubbard Director S.N.H.S.}

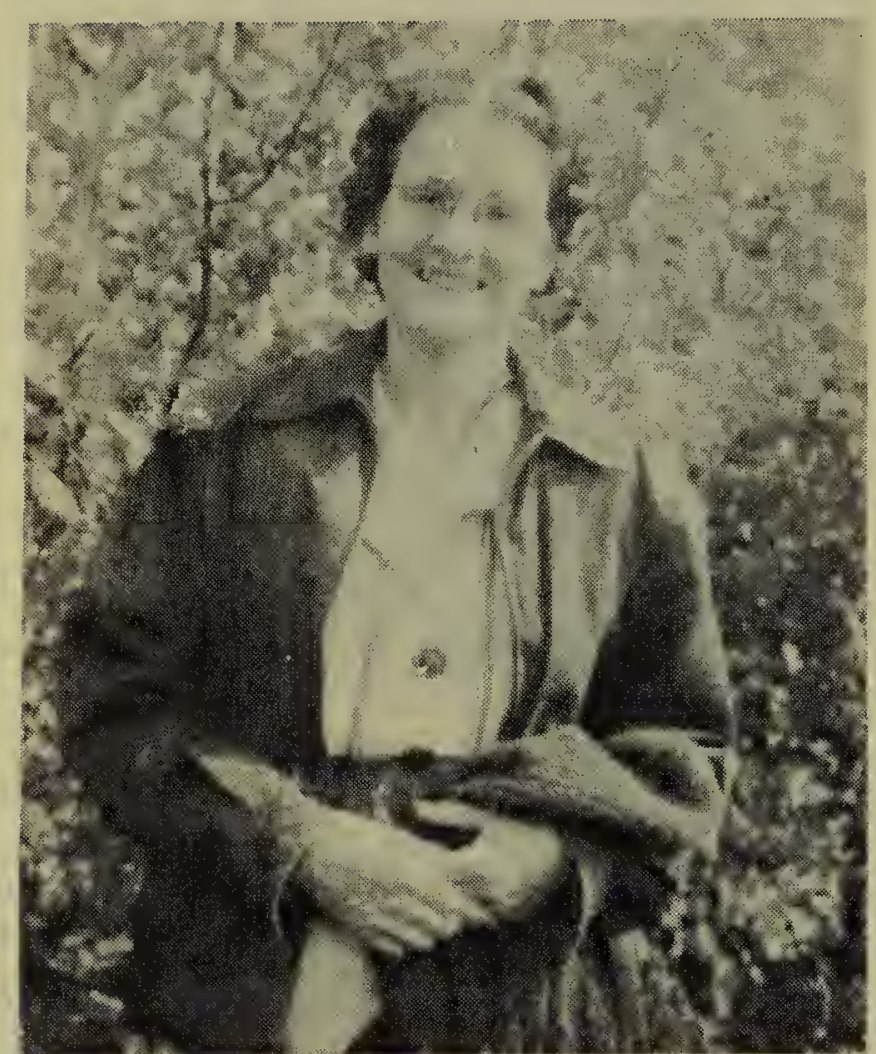

It's not very often that you cal find a real live magician in the strawberry patch -- at least that is what the caterpillar told Derry it was. Derry though it was just an ordinary caterpillar and as he was supposed to he picking strawberries he put it in his pocket. So he was surprised when a little while later he heard someone say.

"I'm a magician."

Derry put his hand up to his ear and there was the caterpillar. 'You're not a magician. You're just a green and black and-- goodness there's a lot of different colours on you! You're just a caterpillar, even if you are a r ather pretty one."

"I'm not pretty--I'm just clever."

"Clever! What can you do?",

"I can turn myself into something different al to gether."

"It's a good trick if you can do it." agreed Derry.

"Why even the conjurer I saw last winter didn't do that. He turned eggs in to rabbits, and rabbits into eggs, but he stayed a conjurer himself all the time."

"You just feed me lots of thistles and I'll show you."

"Thistles have prickles on them -couldn't you eat something el se?"'

"I like thistles."

So Derry put the caterpillar in a tin with some small holes in the lid and fed it lots of thistles. The caterpillar ate so many thistle, and Derry didn't like picking them, that Derry scolded it one day. "If you don't stop making such a pig of yourself you're going to. burst out of your skin.

"Right you are." said the caterpillar, and did just that. And when it had crawled quite leisurely out of its skin it turned around and started eating it.

"Oh, for goodness sake," said
Derry, "you don't have to eat your own skin. I'll, get you some more thistles leaves,"

The next day Derry went to see the caterpillar it had already performed some magic. Instead of a caterpillar there was a pinky brown case hanging on the lid of the tin. A few days later gold spots appeared on the case and various lines and bumps could be seen through it. "Gosh," said Derry to himself, "I believe that caterpill ar is going to turn into a butterfly, I hope it'll be one of those yellow and black fellows with the swallow tails. I hope it hurries up."

Derry got a bit tired of waiting for the caterpillar to perform its magic -but one day it finally got around got it. When he opened up the lid instead of the chrysalis that had been hanging there for days he saw a big butterfly with its wings closed. Derry thought it looked a bit sick so he took it out in the sunshine and soon it spread its wings.

"My," said Derry adiniringly, "you are a pretty butterfly I never thought that you would be that colour. You were green and black and yellow when you were a caterpillar, and kind of brown with gold spots you when were a chrysalis and now you're brown and red and white."

"Didn't I tell you I was a magician?"

"Yes, you sure are. And a good one. But what are you going to do now?',

"I'd like to see a bit of country. I'll find some of my own kind, and fly with them. It'll be fun flitting from flower to flower looking for nectar. And when I get tired of that I'll lay some eggs, and die."'

"Die!" exclaimed Derry. "What do you want to do that for?", answered the butterfly, and away she flew. 